\title{
SURVEI JENTIK NYAMUK Aedes aegypti DI PERUMAHAN WILAYAH KERJA PUSKESMAS MENTENG KOTA PALANGKA RAYA
}

\author{
Rinny Ardina *), Nurhalina*), Suratno*), Dwi Purbayanti *), Fera Sartika*), Agus*) \\ *) Dosen D-III Analis Kesehatan, Fakultas Ilmu Kesehatan, Universitas Muhammadiyah \\ Palangkaraya \\ E-mail : rinyardina@gmail.com
}

\begin{abstract}
Severe dengue or Dengue Hemorrhagic Fever (DHF) occurrence in Palangka Raya is frequently becomes epidemic. The morbidity rate (incidence rate) of DHF cases in Central Kalimantan in 2016 reached 69.1 per 100,000 population with mortality rate (fatality rate) of $1.4 \%$. The morbidity rate reached 278.4 per 100,000 population in Palangka Raya, the second place after North Barito regency. Based on Ministry of Health Republic of Indonesia's Strategic Planning (Renstra), targets for dengue fever in 2016 should be $<49$ per 100,000 population, Central Kalimantan Province has not achieved the target yet. The Central Kalimantan Provincial Health Office reported the epidemy of DHF in 2017 occurred in the working area of Menteng Community Health Center. The report found a case that all family members of a household sufferred from DHF. This community service aimed to educate the community to survey of dengue larvae independently, to develop the community's knowledge and awareness about the importance of support from larvae monitoring specialator Juru Pemantau Jentik (also briefly known as Jumantik) and to increase community participation in DHF prevention movement in Palangka Raya. The method of this community service used site survey, observation, interview, larva examination and reporting of results. The survey activity of larvae showed that Aedes aegypti mosquito larvae was identified in $13.3 \%$ of the houses, mostly found in bathtubs, water shelters and water container of water dispensers.
\end{abstract}

Keywords: Survey of Larvae, Epidemy, Dengue Hemorrhagic Fever, Aedes aegypti, Palangka Raya

\begin{abstract}
ABSTRAK
Kejadian Demam Berdarah Dengue (DBD) di kota Palangka Raya kerapkali disertai dengan Kejadian Luar Biasa (KLB). Pada tahun 2016, angka kesakitan (incidence rate) DBD di Kalimantan Tengah mencapai 69,1 per 100.000 penduduk dengan angka kematian (fatality rate) sebesar 1,4\%. Sedangkan di kota Palangka Raya, angka kesakitan mencapai 278,4 per 100.000 penduduk, kedua terbanyak setelah kabupaten Barito Utara. Berdasarkan target Renstra Kementerian Kesehatan untuk angka kesakitan DBD tahun 2016 itu sebesar < 49 per 100.000 penduduk, dengan demikian Provinsi Kalimantan Tengah belum mencapai target yang telah ditetapkan Kementerian Kesehatan. Melalui laporan Dinas Kesehatan Provinsi Kalimantan Tengah, KLB DBD pada tahun 2017 terjadi di perumahan wilayah kerja Puskesmas Menteng, dimana ditemukan dalam satu rumah tangga DBD menyerang semua anggota keluarga. Tujuan kegiatan ini adalah untuk membantu masyarakat melakukan identifikasi jentik secara mandiri, meningkatkan pengetahuan dan kesadaran masyarakat tentang pentingnya dukungan dari jumantik serta meningkatkan peran serta masyarakat dalam gerakan pengendalian DBD di kota Palangka Raya. Metode yang digunakan adalah survei lokasi, observasi dan wawancara, pemeriksaan jentik dan pelaporan hasil. Dalam kegiatan identifikasi jentik, diperoleh 13,3\%
\end{abstract}


rumah ditemukan jentik nyamuk Aedes aegypti yang sebagian besar ditemukan pada bak mandi, penampungan air dan wadah penampung air dispenser.

Kata Kunci: Survei Jentik, Kejadian Luar Biasa, Demam Berdarah Dengue, Aedes aegypti, Palangka Raya

\section{PENDAHULUAN}

\section{A. Analisis Situasi}

Menurut data yang diperoleh dari Dinas Kesehatan Provinsi Kalimantan Tengah (Dinkes) tahun 2016, kasus Demam Berdarah Dengue (DBD) di Provinsi Kalimantan Tengah dilaporkan terdapat 1762 kasus, lebih banyak bila dibandingkan dengan jumlah kasus DBD pada tahun 2015 sebanyak 1658 kasus, dengan jumlah kematian sebanyak 24 orang sama dengan jumlah kematian pada tahun 2015. Incidence Rate/Angka Kesakitan sebesar 69.1 per 100.000 penduduk dan Fatality Rate/Angka Kematian sebesar $1.4 \%$. Kasus DBD di kota Palangka Raya menunjukkan angka kesakitan mencapai 278,4 per 100.000 penduduk, kedua terbanyak setelah kabupaten Barito Utara (314,4 per 100.000 penduduk).

Angka ini menjadi perhatian oleh Dinkes Provinsi Kalimantan Tengah, sehingga upaya-upaya untuk menanggulangi perkembangbiakkan jentik nyamuk Aedes aegypti penyebab DBD di rumah-rumah penduduk menjadi ketat dilaksanakan. Dinkes Provinsi Kalimantan Tengah bekerjasama dengan Puskesmas Menteng menemukan kasus Kejadian Luar Biasa (KLB) DBD di komplek perumahan di wilayah kerja Puskesmas Menteng, dimana dalam satu rumah tangga diketahui semua anggota keluarga terserang DBD. Berdasarkan hasil observasi di komplek perumahan Jl. G.Obos XII yang merupakan lokasi KLB DBD, diketahui bahwa drainase rumah tangga di lingkungan tersebut kurang baik, sehingga apabila terjadi hujan lebat terus-menerus maka air akan meluap hingga masuk ke beberapa rumah penduduk. Selain itu, faktor perilaku juga menjadi salah satu penyebabnya, karena masih cukup banyak warga yang tidak memeperhatikan wadah terbuka yang berpotensi sebagai tempat hidup nyamuk Aedes aegypti (Fitria, dkk., 2016).

\section{B. Permasalahan}

Demam Berdarah Dengue (DBD) merupakan penyakit yang meresahkan di masyarakat karena dapat berakibat fatal seperti kematian. DBD ditularkan ke manusia melalui gigitan nyamuk Aedes aegypti yang terinfeksi virus Dengue. Pada tahun 2016 Target Renstra Kementerian Kesehatan untuk angka kesakitan DBD tahun 2016 sebesar $<49$ per 100.000 penduduk, dengan demikian Provinsi Kalimantan Tengah terutama kota Palangka Raya belum mencapai target yang telah ditetapkan Kementerian Kesehatan (Dinas Kesehatan Provinsi Kalimantan Tengah, 2016).

Berdasarkan kajian dari Kementerian Kesehatan RI, KLB DBD di Indonesia diakibatkan oleh beragam faktor. Pertama, pada dasarnya penyakit menular termasuk DBD masih endemik di beberapa wilayah karena terdapat vektor nyamuk hampir di seluruh pelosok 
tanah air serta adanya 4 sel tipe virus yang bersirkulasi sepanjang tahun. Faktor kedua adalah lemahnya sistem kewaspadaan dini sehingga penanganan dan pengobatan kasus sebagai intervensi belum dilakukan sebagaimana mestinya. Ketiga, kemudahan alat transportasi memungkinkan

pergerakan/perpindahan alat angkut, penumpang, bahan/barang, dan alat dari satu wilayah ke wilayah lain yang merupakan daerah endemik. Ketiga faktor tersebut didukung dengan masih rendahnya kesadaran masyarakat akan paradigma hidup sehat dan kesadaran pada kondisi lingkungan sekitar sebagai faktor risiko penyebaran penyakit (Pratamawati, 2012).

\section{Tujuan}

Tujuan kegiatan ini antara lain:

1. Membantu masyarakat melakukan identifikasi jentik nyamuk secara mandiri.

2. Meningkatkan pengetahuan dan kesadaran masyarakat tentang pentingnya dukungan dari jumantik.

3. Meningkatkan peran serta masyarakat dalam gerakan pengendalian DBD di kota Palangka Raya.

\section{METODE PELAKSANAAN}

\section{A. Waktu dan Tempat Kegiatan}

Kegiatan dilakukan pada hari Sabtu, tanggal 22 April 2017 dari jam 07.0012.00 WIB. Tempat atau lokasi kegiatan adalah di komplek perumahan Jl. G. Obos XII (wilayah kerja Puskesmas Menteng) kota Palangka Raya, Kalimantan Tengah.

\section{B. Sasaran Kegiatan}

Luaran yang diharapkan dari kegiatan ini adalah masyarakat mampu melakukan survei atau identifikasi jentik nyamuk secara mandiri di rumah tangga masing-masing. Upaya ini akan lebih efektif jika dilakukan oleh kader kesehatan (jumantik) atau tokoh masyarakat misalnya Ketua RT, Ketua RW, Ketua karang taruna dan sebagainya dikarenakan tokoh panutan ini terlibat langsung dalam kegiatan kemasyarakatan dan jelas lebih dekat dengan masyarakat.

\section{Metode Kegiatan}

Analisis situasi meliputi observasi lokasi kegiatan berdasarkan informasi yang telah diperoleh dari Puskesmas Menteng bekerjasama dengn Dinas Kesehatan Provinsi Kalimantan Tengah. Implementasi dilakukan dengan berbagai cara yaitu wawancara diikuti dengan survei atau identifikasi jentik nyamuk di rumah-rumah penduduk, kemudian hasil dicatat serta dilaporkan ke pihak Puskemas Menteng untuk dilakukan evaluasi dan tindaklanjut.

\section{Solusi yang Ditawarkan}

Pemberian edukasi kepada warga tentang tempat-tempat mana saja yang disukai nyamuk Aedes aegypti untuk berkembangbiak dan menunjukkan cara untuk mengidentifikasi nyamuk atau jentik Aedes aegypti agar warga dapat melakukan survei jentik berkala secara mandiri di rumah masingmasing.

\section{HASIL DAN PEMBAHASAN}

Dalam kegiatan identifikasi jentik nyamuk diperoleh 13,3\% rumah ditemukan jentik nyamuk Aedes aegypti dari total 200 rumah yang disurvei dimana sebagian besar 
ditemukan di bak mandi, bak penampungan air, dan wadah penampung air dispenser (Tabel 1).

Tabel 1. Hasil Identifikasi Jentik Nyamuk Aedes aegypti

\begin{tabular}{|l|c|}
\hline $\begin{array}{c}\text { Tempat ditemukan } \\
\text { jentik nyamuk Aedes } \\
\text { aegypti }\end{array}$ & Jumlah rumah \\
\hline Bak mandi & 5 \\
\hline Bak penampungan air & 5 \\
\hline $\begin{array}{l}\text { Wadah penampung air } \\
\text { dispenser }\end{array}$ & 4 \\
\hline Kolam ikan & 1 \\
\hline Kaleng cat & 1 \\
\hline
\end{tabular}

Berikut temuan jentik nyamuk Aedes aegypti pada beberapa kontainer di rumah warga:

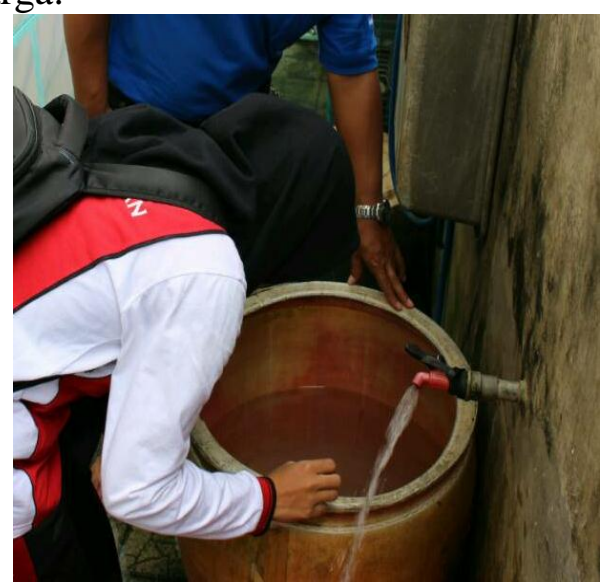

Gambar 1. Bak Penampungan Air (tidak ditutup)

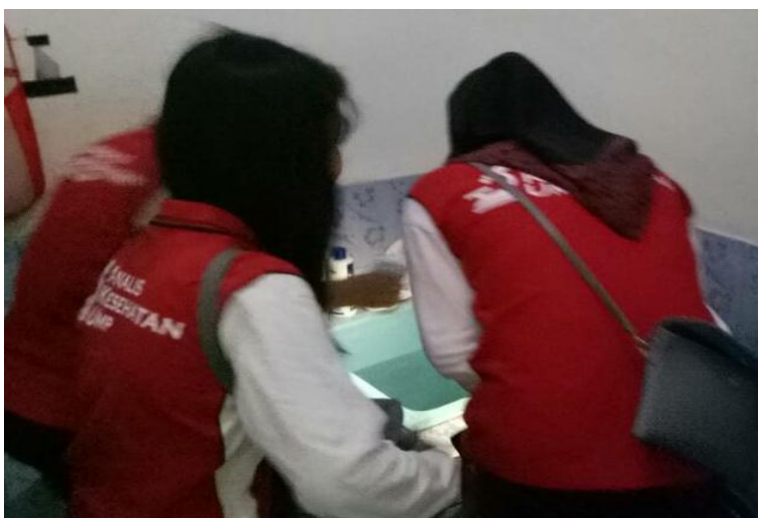

Gambar 2. Bak Mandi

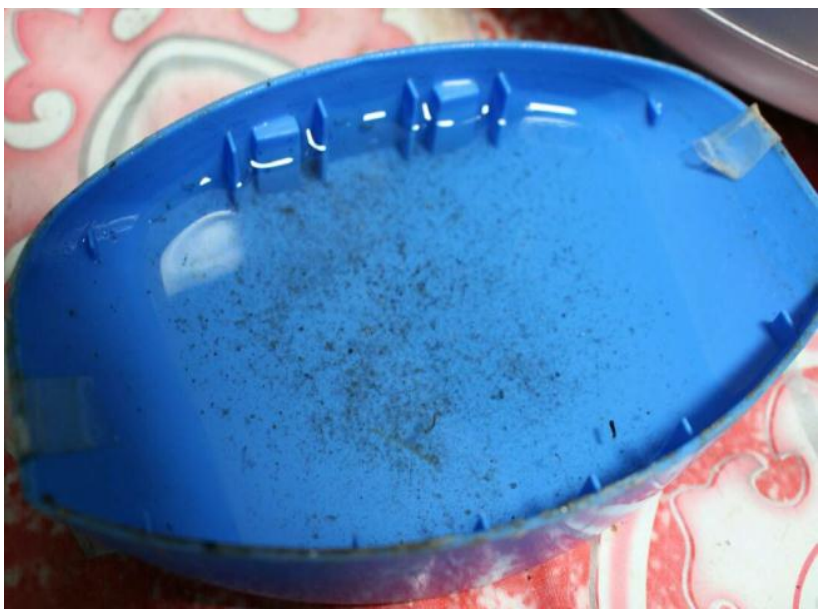

Gambar 3. Wadah Penampung Air Dispenser

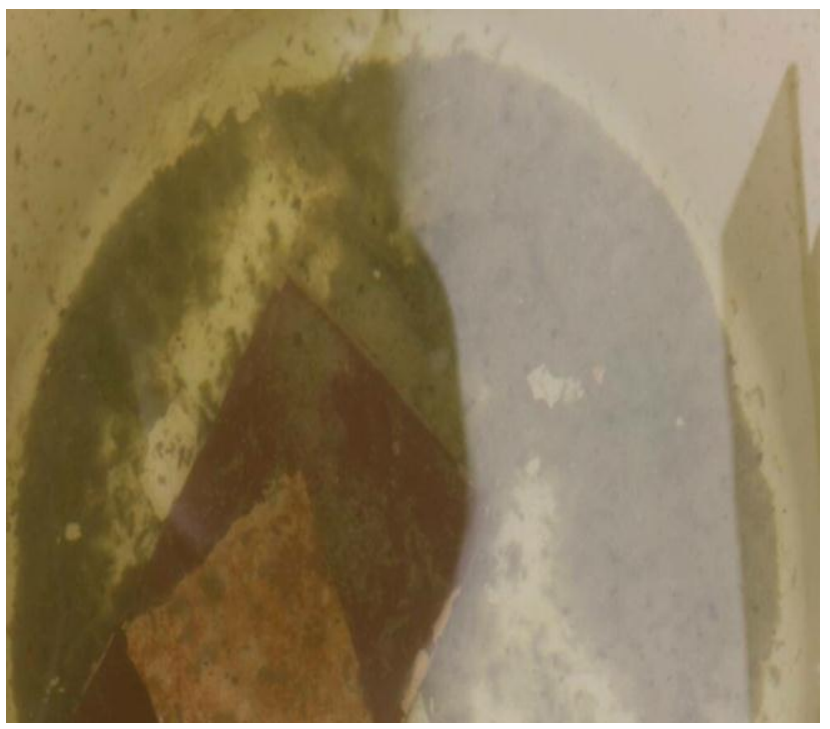

Gambar 4. Bekas Kaleng Cat

Penyebab utama meningkatnya penyebaran geografis dan insiden Demam 
Berdarah Dengue (DBD) di Indonesia diantaranya : (1) kurang efektifnya pengontrolan nyamuk sebagai vektor DBD, (2) urbanisasi yang tidak terencana, dan (3) globalisasi. Nyamuk Aedes aegypti hidup pada rumah-rumah padat penduduk dan menempatkan telur di kontainer yang dibuat oleh manusia dan ini didukung pula oleh faktor iklim di negara tropis yang bercurah hujan tinggi. Aedes aegypti mencari tempat yang sesuai untuk berkembang biak dan jarak tempat-tempat tersebut tidak melampaui jarak terbangnya yaitu mencapai 40-100 meter dari tempat perkembangbiakannya (Sunaryo dan Pramestuti, 2014 ; Gubler, 2011; Fitria, dkk., 2016 ; Browning and Elder, 2009). Kasus KLB (Kejadian Luar Biasa) DBD pada tahun 2017 diketahui dari Dinas Kesehatan Kota Palangkaraya terjadi di komplek perumahan Jl. G. Obox XII yang merupakan wilayah kerja Puskesmas Menteng. KLB ini terjadi diakibatkan padatnya perumahan, kurang baiknya drainase pembuangan limbah rumah tangga dan kurangnya kepedulian warga dalam mengelola kontainer atau barang-barang bekas yang dapat terisi air hujan.

Nyamuk dan jentik Aedes aegypti sering ditemukan di ban bekas, vas bunga, guci, tangki air, dan barang-barang bekas lainnya yang terisi air hujan. Bekas-bekas botol dan sumur air juga berkontribusi meningkatkan kepadatan nyamuk (Gubler, 2011). Namun ada kontainer lain yang sering terlewatkan oleh penghuni rumah yang sebenarnya banyak digunakan nyamuk untuk bertelur dan berkembangbiak yaitu penampungan air pada kulkas dan dispenser (Lutfiana, dkk., 2012). Pada komplek perumahan Jl. G. Obos XII, jentik nyamuk Aedes aegypti ternyata banyak ditemukan pada penampung dispenser (pada 4 rumah) dan penghuni rumah tidak mengetahui bahwa penampung dispenser ini dapat dijadikan nyamuk Aedes aegypti sebagai tempat berkembangbiaknya (Sunaryo dan Pramestuti, 2014).

Masih tingginya angka kepadatan jentik nyamuk Aedes aegypti diakibatkan kurangnya pengetahuan warga tentang tempat perkembangbiakan yang disukai nyamuk Aedes aegypti seperti penampung dispenser yang ditemukan di rumah warga J1. G. Obos XII. Selain itu, kurangnya perhatian dari sebagian masyarakat terhadap pemeliharaan kebersihan tempat penampungan air dan kebersihan lingkungan sekitar juga menjadi faktor penyebabnya. Seperti yang ditemukan pada beberapa rumah di Jl. G. Obos XII, dimana jentik nyamuk banyak ditemukan pada bak penampung air (pada 5 rumah) dan bak mandi (pada 5 rumah) (Sunaryo dan Pramestuti, 2014). Pemahaman tentang penyakit DBD dan upaya penanggulangan yang masih kurang, disebabkan karena masih dibebankannya masalah DBD dan tanggung jawabnya pada sektor kesehatan, padahal DBD harus menjadi tanggung jawab semua pihak karena erat kaitannya dengan kebersihan dan perilaku manusia. Selain itu, dalam menyusun suatu program kegiatan, diperlukan peran serta masyarakat yang optimal sejak awal proses perencanaan (Chadijah, dkk., 2011).

Pemberantasan Sarang Nyamuk (PSN) melalui 3M Plus telah dicanangkan sejak lama oleh Kementerian Kesehatan Republik Indonesia dengan melibatkan masyarakat dan memfasilitasi terbentuknya tenaga jumantik. Pemeriksaan jentik merupakan pemeriksaan tempat-tempat perkembangbiakan nyamuk Aedes aegypti yang dilakukan secara teratur oleh petugas kesehatan atau kader atau petugas pemantau jentik (jumantik). Tujuan pemeriksaan jentik adalah untuk melakukan pemeriksaan jentik nyamuk penular DBD dan memotivasi keluarga dan masyarakat dalam melaksanakan PSN DBD. Dengan kunjungan yang berulang-ulang disertai 
penyuluhan diharapkan masyarakat dapat melakukan PSN DBD secara teratur dan terus-menerus (Depkes RI, 2010). Berdasarkan hasil penelitian Browning and Elder (2009), diketahui bahwa durasi monitoring melalui penyuluhan oleh kader kesehatan untuk mengeliminasi kontainer berisi air antara 18 minggu hingga 15 bulan menunjukkan penurunan angka populasi Aedes aegypti sebesar $41,6 \%$ di bulan ke-12 di negara Kuba.

Perlu diingat kembali, meskipun perlindungan dan pengosongan air di kontainer-kontainer sangatlah sederhana dan murah dalam upaya mengurangi populasi nyamuk Aedes aegypti, namun faktanya masih ada beberapa kendala yang terjadi diantaranya: (1) pengosongan dan penutupan kontainer yang masih tidak benar, (2) adanya kesalahpahaman dalam pengelolaan kontainer, misalnya warga lupa untuk menutupnya kembali, (3) upaya peningkatan pengetahuan kadang juga tidak adekuat untuk mengubah perilaku masyarakat. Oleh sebab itu, peranan dari pemilik rumah perorangan, ketua komunitas, dan badan pemerintahan sebenarnya perlu ditingkatkan agar dapat membantu melanjutkan program eliminasi DBD (Browning and Elder, 2009). Menurut wawancara dengan kepala rumah tangga di lokasi survei jentik, diketahui bahwa penghuni rumah sudah ada beberapa yang mampu melakukan identifikasi jentik nyamuk dan mengikuti program $3 \mathrm{M}$ plus, sedangkan penghuni rumah lainnya yang masih kurang dalam pengetahuannya terhadap tempat-tempat perkembangbiakkan jentik nyamuk Aedes aegypti diberikan edukasi dengan menunjukkan lokasinya secara langsung dan cara mencegahnya.

\section{SIMPULAN DAN SARAN}

\section{A. Simpulan}

Dalam kegiatan identifikasi jentik, diperoleh 13,3\% rumah ditemukan jentik nyamuk Aedes aegypti yang sebagian besar ditemukan pada bak mandi, penampungan air dan wadah penampung air dispenser.

\section{B. Saran}

Survei jentik harus dilakukan secara berkelanjutan dengan memberdayakan masyarakat setempat yang didampingi oleh petugas kesehatan untuk mengurangi angka penularan DBD. Survei jentik juga harus tetap dimonitoring oleh Puskesmas atau Dinas Kesehatan Kota Palangkaraya sehingga dalam pelaksanaannya dapat berjalan dengan baik serta informasi tentang hasil survei dapat dievaluasi untuk menilai keberhasilan PSN (Pemberantasan Sarang Nyamuk) yang dilakukan.

\section{DAFTAR PUSTAKA}

Browning, K.K., and John, P. E. 2009. Multi-modal Aedes aegypti Mosquito Reduction Interventions and Dengue Fever Prevention. Tropical Medicine and International Health. 14 (12) : 1542-1551.

Chadijah,S., Rosmini, dan Halimuddin. 2011. Peningkatan Peranserta Masyarakat Dalam Pelaksanaan Pemberantasan Sarang Nyamuk DBD (PSN-DBS) di Dua Kelurahan di Kota Palu, Sulawesi Tengah. Media Litbang Kesehatan. 21 (4) : 183-190.

Departemen Kesehatan Republik Indonesia :

Direktorat Jenderal Pengendalian Penyakit dan Penyehatan Lingkungan. 2010. Pencegahan dan Pemberantasan Demam Berdarah Dengue di Indonesia. Jakarta.

Dinas Kesehatan Provinsi Kalimantan Tengah. 2016. Profil Kesehatan 2016 Provinsi Kalimantan Tengah. Palangka Raya.

Fitria, N., Nur, E. W., dan Retno, M. 2016. Hubungan Praktik Buang Sampah, 
Praktik Penggunaan Insektisida, Container Index, dan Lingkungan Fisik Rumah Dengan Kejadian DBD (Studi di Empat Rumah Sakit di Kota Semarang). Jurnal Kesehatan Masyarakat 2 (5) : 77-84.

Gubler, D. J. 2011. Dengue, Urbanization and Globalization : The Unholy Trinity of the $21^{\text {st }}$ Century. Tropical Medicine and Health. 39 (4) : 3-11.

Lutfiana, M., Tri, W., Zulmiati, dan Latifah, N. 2012. Survei Jentik Sebagai Deteksi Dini Penyebaran Demam Berdarah Dengue (DBD) Berbasis Masyarakat dan Berkelanjutan. Jurnal Ilmiah Mahasiswa. 2 (1) : 56-63.

Pratamawati, D. A. 2012. Peran Juru Pemantau Jentik dalam Sistem Kewaspadaan Dini Demam Berdarah Dengue di Indonesia. Jurnal Kesehatan Masyarakat Nasional. 6 (6) : 243-248.

Sunaryo dan Nova, P. 2014. Surveilans Aedes aegypti di Daerah Endemis Demam Berdarah Dengue. Jurnal Kesehatan Masyarakat Nasional. 8 (8) : 423-429. 